\title{
Biochemical Conversion Processes of Lignocellulosic Biomass to Fuels and Chemicals - A Review
}

\author{
Simone Brethauer and Michael H. Studer*
}

\begin{abstract}
Lignocellulosic biomass - such as wood, agricultural residues or dedicated energy crops - is a promising renewable feedstock for production of fuels and chemicals that is available at large scale at low cost without direct competition for food usage. Its biochemical conversion in a sugar platform biorefinery includes three main unit operations that are illustrated in this review: the physico-chemical pretreatment of the biomass, the enzymatic hydrolysis of the carbohydrates to a fermentable sugar stream by cellulases and finally the fermentation of the sugars by suitable microorganisms to the target molecules. Special emphasis in this review is put on the technology, commercial status and future prospects of the production of second-generation fuel ethanol, as this process has received most research and development efforts so far. Despite significant advances, high enzyme costs are still a hurdle for large scale competitive lignocellulosic ethanol production. This could be overcome by a strategy termed 'consolidated bioprocessing' (CBP), where enzyme production, enzymatic hydrolysis and fermentation is integrated in one step - either by utilizing one genetically engineered superior microorganism or by creating an artificial co-culture. Insight is provided on both CBP strategies for the production of ethanol as well as of advanced fuels and commodity chemicals.
\end{abstract}

Keywords: Biorefinery · Cellulase · Consolidated bioprocessing (CBP) - Sugar platform · Synthetic microbial consortium

\section{Introduction}

In order to relieve the world's dependence on fossil fuels, alternative sustainable sources for energy and chemicals must be exploited. A possible alternative source is lignocellulosic biomass - such as wood, agricultural residues or dedicated energy crops - as it is available at large scale at low cost and does not compete with food and feed applications. ${ }^{[1]}$ In the future, lignocellulose will be processed in a biorefinery that integrates biological and/or chemical conversion processes to produce a range of fuels, power, materials, and chemicals to maximize the value derived from the feedstock and minimize waste streams. ${ }^{[2]}$ Generally, a biorefinery is based on one or several different platforms from which the product portfolio is developed. The biochemical sugar platform relies on lignocellulosic biomass as a source of fermentable sugars that are released by enzymatic hydrolysis and then converted by different microorganisms to the desired final products (Fig. 1). ${ }^{[3]}$ In this review, we will briefly introduce the structure of lignocellulosic biomass, followed by a discussion of the generic technologies of the sugar platform, i.e. biomass pretreatment and enzymatic hydrolysis. Then, we will provide insight on the technology, commercial status and future prospects of the

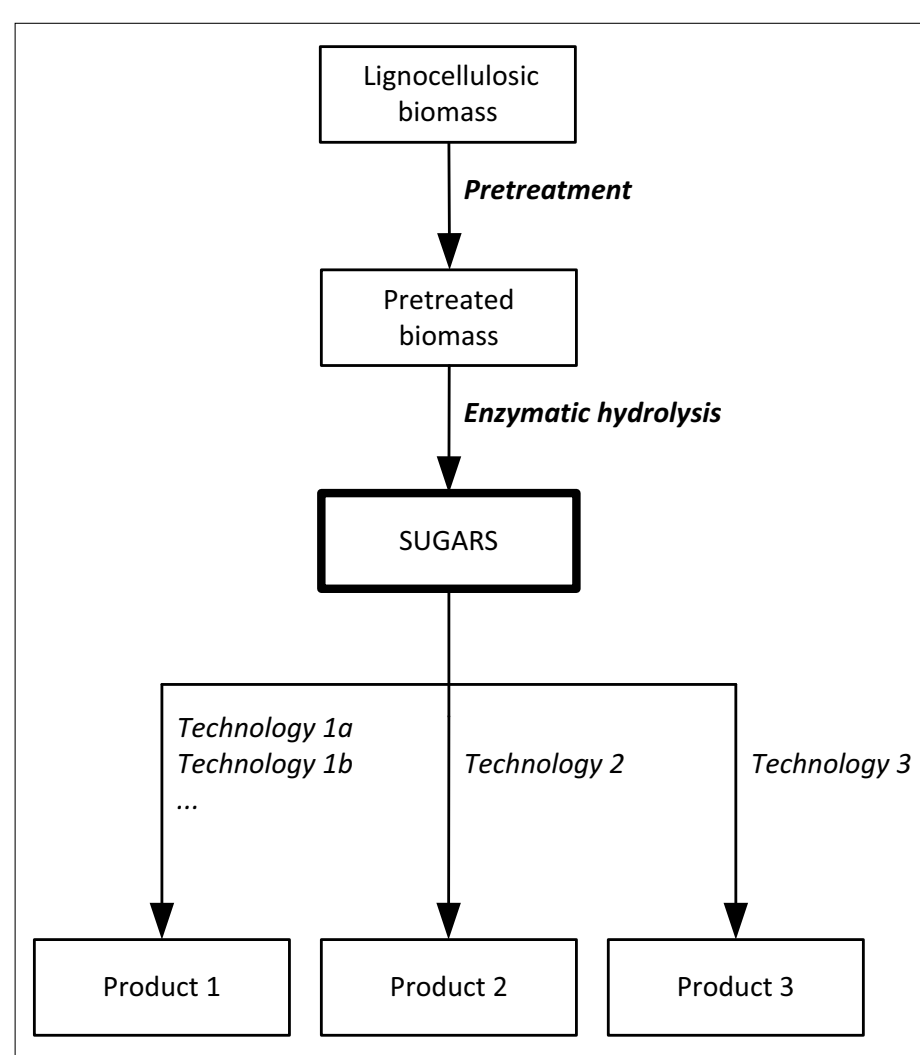

production of second-generation fuel ethanol and highlight the recent advances of consolidated bioprocessing by genetically engineered microorganisms and synthetic microbial consortia for the production of ethanol and other bulk chemicals.
Fig. 1. Simplified depiction of the biochemical sugar platform. The biochemical sugar platform is based on lignocellulosic biomass as a source of (mono-)sugars that are released by pretreatment and enzymatic hydrolysis. The sugars are converted through a range of technologies such as fermentation or aqueous phase reforming to the desired products. 


\section{The Structure of Lignocellulosic Biomass}

Lignocellulose is a complex material that builds the structural backbone of all plant cell walls and is composed of mainly cellulose (40-50\%), hemicellulose (25$30 \%)$ and lignin (15-20\%) (see Fig. 2). ${ }^{[4]}$ Cellulose is a linear homogenous polymer of 7'000 to $15^{\prime} 000$ glucose units linked by $\beta-1-4$ glycosidic linkages that are further stabilized by intrachain hydrogen bonding. [5] Cellobiose is the repeating unit of cellulose, since adjacent glucose molecules are rotated $180^{\circ}$ with respect to their neighbors. ${ }^{[6]}$ Hemicellulose is a branched or linear heteropolymer of 200-400 units of different pentoses (C5 sugars; xylose, arabinose), hexoses (C6 sugars; mannose, glucose, galactose) and uronic acids with an amorphous structure. Depending on the plant, the hydroxyl groups of the sugars can be partially substituted with acetyl groups. ${ }^{[7]}$ Lignin is an amorphous crosslinked polymer of the three phenyl propane units $p$-coumaryl, coniferyl and sinapyl alcohol.

Together these three components build a composite material, the exact molecular structure of which is still under investigation. ${ }^{[8]}$ However, it is generally understood that the linear cellulose chains arrange themselves to microfibrils of 3-4 nm diameter held together by strong interchain hydrogen bonds and containing highly ordered crystalline structures as well as amorphous regions. ${ }^{[5]}$ Hemicellulose is attached to the outside of the microfibrils by hydrogen bonding and is covalently linked to lignin by ester bonds. This structure gives the plant mechanical stability and protection against microbial deconstruction. ${ }^{[9]}$

\section{Pretreatment}

In a bioprocessing context, the natural resistance of plant cell walls to microbial and enzymatic deconstruction is often referred to as 'biomass recalcitrance'. ${ }^{[10]}$ To overcome the inherent recalcitrance of lignocellulose to the release of fermentable sugars, a physico-chemical pretreatment is mandatory as the first step in the bioprocessing route to the desired chemical. ${ }^{[11]}$ While the focus of this review is on the downstream enzymatic and microbial conversion processes, we will in this section briefly introduce the pretreatment technologies to provide a rounded picture of the sugar platform biorefinery. In-depth information on pretreatment processes is summarized elsewhere in several excellent reviews. [12]

Generally, the aim of the pretreatment is to disrupt the cell wall structure and to improve access of the hydrolytic enzymes to the sugar polymers. A variety of pretreatment technologies is investigated, which employ for example steam, ${ }^{[13]}$ hot water, ${ }^{[14]} \mathrm{SO}_{2},{ }^{[15]}$ dilute sulfuric acid,[16] phosphoric acid, ${ }^{[17]}$ ammonia, ${ }^{[18]}$ ionic liquids, ${ }^{[19]}$ or tetrahydrofuran as co-solvent. [20] The acidic and water-only pretreatments typically hydrolyze a large fraction of the hemicellulose whereas the fraction of released monomeric sugars increases with decreasing pretreatment $\mathrm{pH}$. In the alkaline pretreatments, lignin-carbohydrate ester linkages are targeted, leading to the partial extraction of lignin. Furthermore, the hemicellulose is deacetylated, which has been shown to be beneficial for the subsequent enzymatic hydrolysis. Overall, the thermochemical pretreatment step facilitates the access of the enzymes to its substrates, enhancing the rate and yields of the subsequent enzymatic hydrolysis by 3-10-fold.[21] However, there are also unwanted effects of the pretreatment, namely the generation of compounds that are inhibitory to the enzymes or the organisms used for fermentation. The furan derivatives hydroxymethylfurfural and furfural are formed under elevated pressure and temperature as degradation products of hexoses and pentoses, respectively.

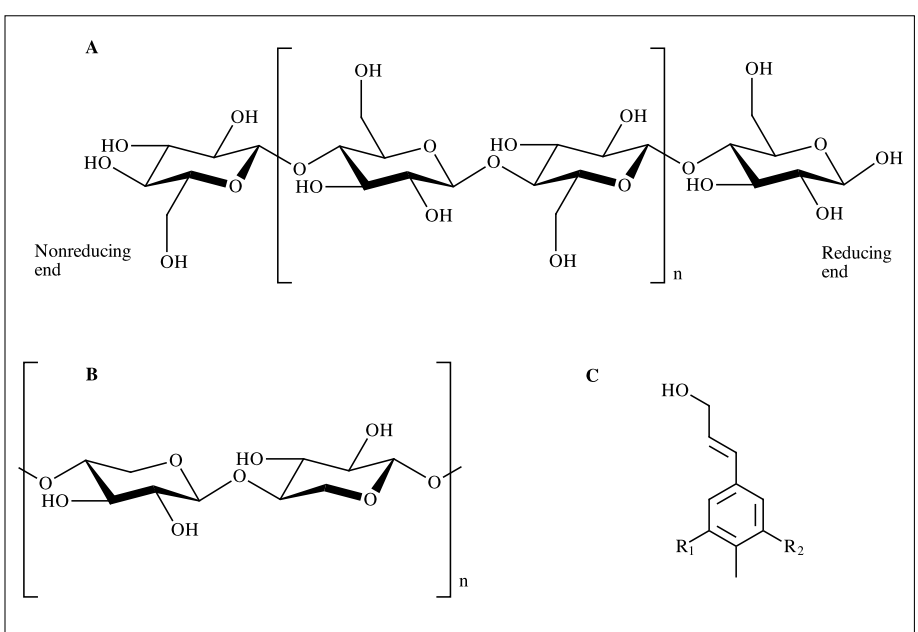

Especially, the soluble hemicellulosic sugars such as xylose and mannose are susceptible to degradation. Acetic acid is a further well known fermentation inhibitor that is released from the hemicellulose while the undesired phenolic compounds originate from the decomposition of lignin. ${ }^{[22]}$

Overall, an ideal pretreatment method has to maximize the sugar yields of the subsequent enzymatic hydrolysis, while minimizing the degradation of sugars and the formation of inhibitory compounds. Furthermore, low energy, capital and operating costs are critical for a commercially successful pretreatment method. Unfortunately, no pretreatment method is universally successful for all types of biomass and the conditions (e.g. residence time, temperature, catalyst concentration) have to be carefully optimized for the targeted feedstock. On a commercial scale, continuous steam explosion pretreatments dominate (see Table 1 in Section 5), as this technology is related to sulphite pulping, which has been applied for a long time on a large scale in the pulp and paper industry. ${ }^{[23]}$ Furthermore, a steam gun is best suited to deal with large particles and the particle size is reduced during the rapid expansion step in a very energy efficient way. ${ }^{[24]}$

\section{Enzymatic Saccharification of Cellulose}

The enzyme-mediated hydrolysis of the cellulosic and hemicellulosic biomass components to release soluble and fermentable sugars is the central step of any biorefinery based on the sugar platform. Several microorganisms possess the native ability to deconstruct lignocellulosic biomass and to utilize the sugar products as sole carbon source for growth. For digestion of native cell-wall materials, three categories of enzymes are considered necessary: cellulases, hemicellulases, and accessory enzymes (e.g. hemicellulose debranching enzymes or phenolic acid esterase). ${ }^{[10]}$ Discussed below in more detail are the cellulolytic enzymes that are expressed either in the form of free, non-complexed cellulases or as cellulosomes.[25] components of biomass.

A) Cellulose: a homopolymer of $\beta-1-4$ linked glucose units. B) Hemicellulose: exemplarily depicted here as xylan, a homopolymer of the $\mathrm{C} 5$ sugar xylose. C) Building blocks of lignin: coniferyl alcohol $\left(\mathrm{R}_{1}=\mathrm{H}, \mathrm{R}_{2}=\right.$ $\mathrm{OCH}_{3}$ ), sinapyl alcohol $\left(\mathrm{R}_{1}=\mathrm{R}_{2}=\mathrm{OCH}_{3}\right)$ and $p$-Coumaryl alcohol $\left(R_{1}=R_{2}=H\right)$.

\subsection{Non-complexed Fungal Cellulases}

The research efforts on fungal cellulases had their beginning during the Second World War as the US military stationed in the South Pacific was plagued by 'jungle rot' that destroyed the cotton tents and other equipment. The Army established a program to understand its cause that led filamentous fungus Trichoderma reesei (now classified as Hypocrea jecorina). It was soon realized that its ability to digest to the isolation of the aerobic, mesophilic 
cotton can be utilized to produce fermentable sugars from cellulosic biomass.[26] In order to hydrolyze the cellulose fibers, a set of different enzymes have to act in concert. This cellulolytic mixture called cellulase comprises mainly three types of enzymes: endoglucanases (EG), which cleave internal $\beta$-1-4-glucosidic bonds in soluble and insoluble substrates; exoglucanases or cellobiohydrolases $(\mathrm{CBH})$, which act on both the reducing and non-reducing ends of cellulose chains to release shortchain cello-oligosaccharides like e.g. cellobiose and $\beta$-glucosidases (BG), which hydrolyze soluble cello-oligosaccharides to glucose (Fig. 3). The three types of enzymes act synergistically, i.e. the activity exhibited by the mixture of components is greater than the sum of the individual activities evaluated separately. ${ }^{[6]}$ The $\mathrm{CBH}$ EG (exo-endo) synergy can be rationalized by the generation of a greater number of free crystal ends by the random cutting of cellulose chains by EG, while BG elimi- nates the strong product inhibition of $\mathrm{CBH}$ activity by hydrolyzing cellobiose to glucose. ${ }^{[27]}$ Most important for the efficient hydrolysis of crystalline cellulose are the CBHs, which generally show a modular construction consisting of the carbohydrate binding module connected to the catalytic module via a flexible linker. ${ }^{[27]} \mathrm{CBH}$ binds to cellulose with the carbohydrate binding module, followed by the isolation (decrystallization) of a single cellulose chain that is directed into the active site tunnel of the catalytic domain where one cellobiose unit is cleaved off per catalytic event. ${ }^{[10]}$

\subsection{Cellulosomes}

An alternative microbial strategy for biomass deconstruction employed exclusively by anaerobic microorganisms is the assembling of the hydrolytic enzymes in a multi-protein complex called cellulosome that is typically attached to the cell wall. ${ }^{[28,29]}$ Here, multiple catalytic components are bound via strong non-covalent

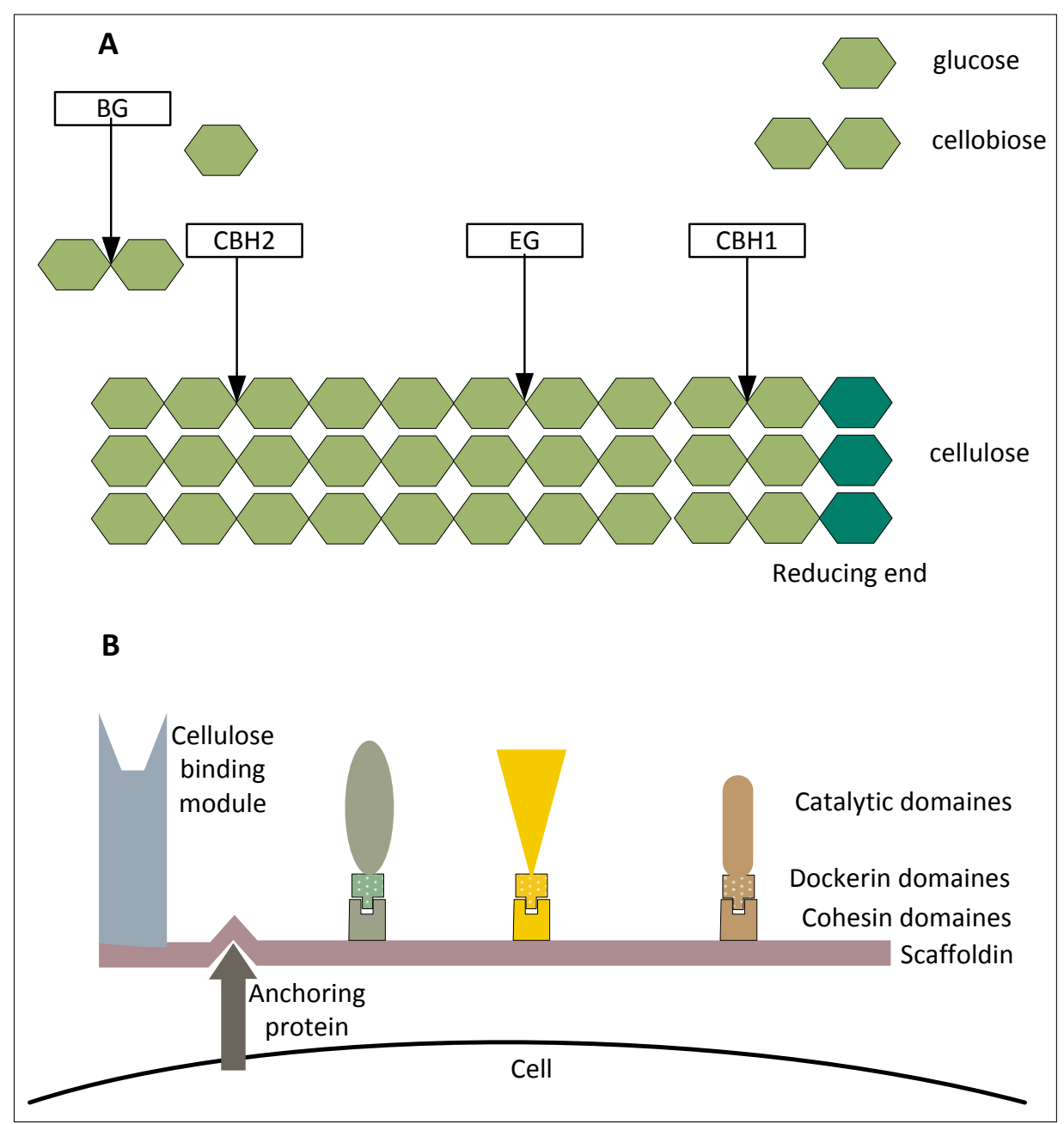

Fig. 3. Enzymes for cellulose hydrolysis. A) For the hydrolysis of cellulose, three types of enzymes are working synergistically: endoglucanases $(E G)$ are cleaving internal $\beta-1-4-$ glucosidic bonds, exoglucanases or cellobiohydrolases $(\mathrm{CBH})$ act on the ends of cellulose chains to release shortchain cello-oligosaccharides like cellobiose, and $\beta$-glucosidases (BG) hydrolyze cellobiose to glucose. B) Schematic depiction of a cellulosome bound to the cell surface with an anchoring protein: The scaffoldin contains a cellulose binding module and several cohesin domains to which the individual hydrolytic enzymes are bound through strong non-covalent protein-protein interactions via their dockerin domains. protein-protein interactions between dockerin molecules of the individual enzymes and the cohesion molecules of the scaffoldin that builds the backbone of the cellulosome (see Fig. 3). This architecture allows for spatial proximity of enzymes with complimenting catalytic activities enabling cellulose fragments to be collected at high concentrations close to the enzymes which results in a minimum of negative feedback products and thus very efficient biomass deconstruction. ${ }^{[28]}$ Attachment to the cellulose surface occurs with a carbohydrate binding module which is typically a part of the scaffoldin. Natural cellulosomes are very complex, e.g. the cellulosomal organism Clostridium thermocellum possesses eight putative scaffoldins and more than 70 dockerin-containing subunits with high catalytic diversity allowing the structural complexity of their target substrates to be tackled efficiently, to which also the composition and activity of the cellulosome can be adjusted.[28]

\subsection{Reaction Kinetics}

The hydrolysis of cellulose by cellulase is a complex reaction where different types of enzymes act on a heterogeneous insoluble substrate as well as on soluble intermediates. Thus, also the accurate mathematical description of the reaction kinetics taking into account all relevant substrate and enzyme aspects has proven to be challenging.[30] Substrate-related factors influencing the reaction kinetics include amongst others available surface area, accessibility, crystallinity, hemicellulose and lignin content and degree of polymerization, whereas enzyme-related factors are e.g. product inhibition, enzyme synergy and enzyme deactivation. ${ }^{[30,31]}$ To complicate matters further, many of these factors are dynamic and change during the course of the reaction, which explains the observed decrease of the reaction rate by 2 to 3 orders of magnitude at high degrees of conversion. ${ }^{[32]}$ Generally, it can be stated that cellulose hydrolysis is a rather slow process. Lynd et al. compiled reported initial specific hydrolysis rates of Avicel by different enzymes that ranged from 0.01 to $13.2 \mu \mathrm{mol} \mathrm{min}{ }^{-1} \mathrm{mg}^{-1} \cdot{ }^{[33]}$ Klyosov reported $\mathrm{k}_{\text {cat }}$ values of $0.5-0.6 \mathrm{~s}^{-1}$ for $T$. reesei cellulase compared to $58 \mathrm{~s}^{-1}$ for amylase. [34] Together with the decline of reaction rate over time, this translates to typical reaction times of three to five days if reasonable yields $(>70 \%)$ are targeted.

\subsection{Current Status and Future Prospects}

Nowadays, cellulases have numerous applications in industrial processes, e.g. as detergent or animal feed additive, in cotton and paper manufacturing or in juice extraction making them currently the third 
largest industrial enzyme class by market volume. ${ }^{[35]}$ The most common commercially available cellulases are produced by Trichoderma and Aspergillus species. These cellulolytic fungi readily secret proteins with yields above $20 \mathrm{~g} / \mathrm{L}$ in submerged fermentations, but costs are high due to long fermentation times and high power demand for broth aeration. ${ }^{[11]}$ For low value applications such as biofuels the production costs are still too high, despite the funding efforts of the US Department of Energy to commercial enzyme producers such as Novozymes and DuPont (former Genencor) that resulted in a 10 to 20 fold cost reduction. ${ }^{[36]}$

Thus, intensive research programs are underway to engineer more efficient enzymes and production systems that can be broadly classified in three areas (excluded here the development of consolidated bioprocessing strains that is described in a separate section).

\subsubsection{Development of Recombinant Cellulase Expression Platforms}

Although several natural cellulolytic fungi have been developed into industrial strains, there is a widespread interest to develop heterologous recombinant expression platforms with the overall goal to achieve higher enzyme concentrations and activities. ${ }^{[29]}$ The investigated expression platforms include bacteria (e.g. Escherichia coli or Bacillus subtilis), yeast (e.g. Saccharomyces cerevisiae or Pichia pastoris), fungi (Trichoderma reesei or Aspergillus niger) or plants (e.g. Arabidopsis thaliana or maize), with the respective advantages and challenges summarized in recent comprehensive reviews. ${ }^{25,27,29]}$

Recombinant expression hosts are also of importance for the engineering of so-called designer cellulosomes. ${ }^{[37]}$ Their above-described modular construction with a specific interaction between one cohesin and one matching dockerin domain allows the defined design of new artificial multi-protein complexes. To this end, the carbohydrate binding modules of free cellulases are replaced with different dockerin domains and artificial scaffoldins containing the matching cohesion domains for specific incorporation of the catalytic units as well as a carbohydrate binding module are constructed. [38] Designer cellulosomes can be used free in solution or alternatively anchored on the surface of e.g. S. cerevisiae. Currently, the most complex designer cellulosome contained six different catalytic units and showed a 1.6 times higher efficiency in wheat straw hydrolysis compared to the free enzymes. ${ }^{[39]}$ However, so far it has not been possible to outperform the natural cellulosome of $e . g$. C. thermocellum.

\subsubsection{Protein Engineering of Cellulases}

One goal for protein engineering of cellulases is the development of thermostable variants, as higher reaction temperatures increase reaction rates but also because thermophilic enzymes are more stable at standard operating temperatures. Screening of random mutant libraries, ${ }^{[40]}$ rational introduction of disulfide bridg$\mathrm{es}^{[41]}$ and construction of chimeric enzyme libraries obtained by recombination of protein blocks from three different parent $\mathrm{CBHs}^{[42]}$ have been successfully applied. For example, the best enzyme chimeras showed an up to 3'600 times longer half life time at $63{ }^{\circ} \mathrm{C}$ and increased the possible reaction temperature by $15{ }^{\circ} \mathrm{C} .{ }^{[42]}$ Other protein engineering targets are for decreased product inhibition, altered $\mathrm{pH}$ optima or decreased unproductive binding on lignin. ${ }^{[43]}$

The improvement of cellulase activity itself is more difficult than e.g. engineering thermostablity, most likely because high cellulase activity is connected to a direct growth advantage during the natural evolution of the host organism in nature. A further difficulty is the design of a meaningful screening procedure as the final target reaction - the enzymatic hydrolysis of real biomass - shows a high complexity with different enzymes acting synergistically on variable substrates. ${ }^{[38]}$

\subsubsection{Identification of Auxiliary Enzymes for more Efficient Enzyme Cocktails}

Recently, different non-hydrolytic enzymes with auxiliary activities that support enzymatic hydrolysis of cellulose, also called 'cellulase-enhancing factors', were described. ${ }^{[4]}$ Lytic polysaccharide monooxygenases catalyze oxidative cleavage of polysaccharide chains directly on the surface of the solid substrate without the need to cleave off one single cellulose chain and are applied in Novozymes cellulase complex Cellic CTec3. ${ }^{[45]}$ Incubation of biomass with swollenin, an enzyme originally isolated from Trichoderma reesei is discussed as an alternative to physicochemical pretreatment methods due to the enzyme's ability to decrease crystallinity and increase accessibility by disrupting hydrogen bonding between polysaccharides. ${ }^{[46]}$

\section{Production of Ethanol from Lignocellulosic Biomass}

The conversion of lignocellulosic biomass to ethanol as target product has received most research and development efforts. Ethanol is a widely applied biofuel comprising about $10 \%$ of the fuel mix in the US and $30 \%$ of the mix in Brazil, corre- sponding to a yearly ethanol consumption of 75 billion liter in these two countries. ${ }^{[11]}$ Up to $10 \%$ of anhydrous ethanol can be blended into gasoline to be utilized in standard combustion engines. Flexiblefuel vehicles, which are very common in Brazil, can be run with any gasoline ethanol mixture up to an ethanol concentration of $85 \%$ (called E85). ${ }^{[11]}$ An interesting but far less known option is fueling adapted heavy duty diesel vehicles such as trucks or buses with ED95 consisting of $95 \%$ hydrous ethanol supplemented with an ignition improver, a lubricant and a corrosion protection. ED95 produces very low emissions of particulates, nitrogen oxides and hydrocarbons compared to equivalent diesel usage. ${ }^{[47]}$

Nowadays fuel ethanol is mainly produced by fermentation of sugars derived from first-generation feedstocks such as sugar cane or corn. Due to ethical (food vs. fuel) and environmental reasons, second-generation ethanol produced from lignocellulosic biomass is the better choice for the future and the technology for its production is reviewed in the following sections.

\subsection{Processes Based on Externally Produced Cellulases}

The biological conversion of lignocellulosic biomass to ethanol comprises four main unit operations: the physicochemical pretreatment of the biomass, the enzymatic hydrolysis of the carbohydrates to a fermentable sugar stream, the conversion of the mixed sugar stream by suitable microorganisms to ethanol and the product recovery. In a full-scale plant, further necessary utilities include $e . g$. wastewater treatment facilities and boilers for steam and electricity generation. Depending on the type of biomass, the pretreatment method and the available enzymes and microorganisms, the four main steps might be supplemented by several separation, washing and polishing steps adding to the complexity of the process. ${ }^{[48]}$ Furthermore, there are opportunities to integrate some of the unit operations in one step as we discuss in more detail in the following description of the possible process configurations (Fig. 4).

The intermediate biomass material after pretreatment typically consists of a solid phase and a liquid phase, with the amount and composition varying depending on the chosen pretreatment method. This mixture, often called 'whole slurry' can either be subjected directly to enzymatic hydrolysis or the solid and the liquid phase are separated, the solids (containing most of the cellulose) are washed and the liquid phase (containing the solubilized sugars, e.g. xylose) is detoxified.[49] The additional separation, washing, and pol- 


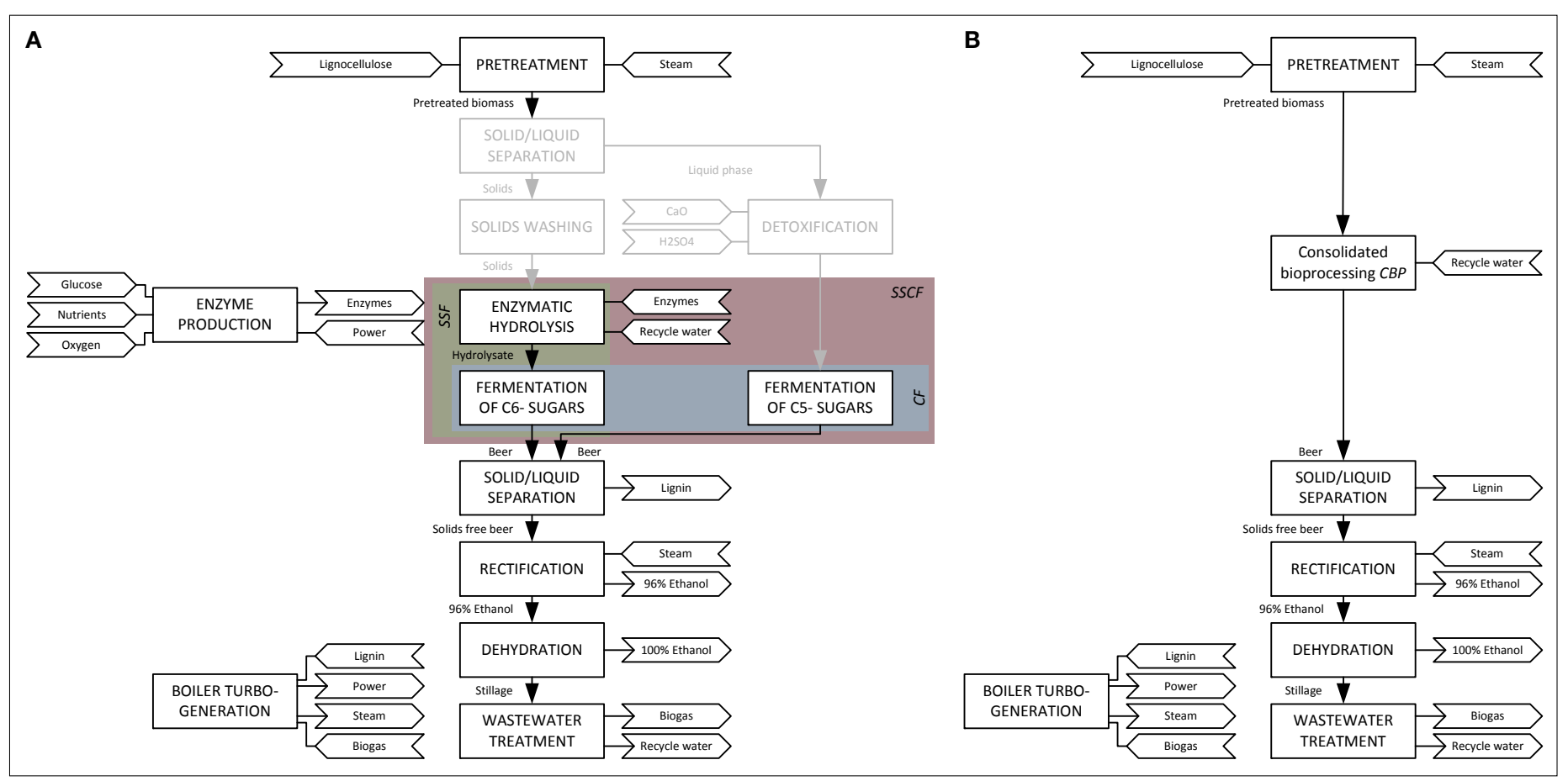

Fig. 4. Process flow sheet for the production of cellulosic ethanol. A) The three main unit operations of cellulosic ethanol production are the pretreatment, the enzymatic hydrolysis of the biomass carbohydrates and the fermentation of the released sugars to ethanol. Optional, some unit operations can be integrated as depicted in the boxes: CF, co-fermentation; SSF, simultaneous saccharification and fermentation; SScF, simultaneous saccharification and co-fermentation. The three main steps are optionally supplemented by several separation, washing and polishing steps (depicted in grey) to deal with fermentation and enzymatic hydrolysis inhibitors released in the pretreatment step. Further unit operations are for product purification, steam and power generation, enzyme production and wastewater treatment. B) The integration of enzyme production, enzymatic hydrolysis and co-fermentation in one step - so-called consolidated bioprocessing (CBP) is the most advanced processing option.

ishing steps are necessary if the pretreatment releases inhibitory compounds that negatively impact enzymatic hydrolysis and fermentation and if no microorganism is available that is able to ferment a mixed C5 and C6 sugar stream. ${ }^{[48]}$ Possible detoxification methods are e.g. overliming (temporarily raising the $\mathrm{pH}$ to $9-11$ with lime), adsorption of inhibitors on ion exchange resins or activated charcoal or enzymatic treatment with laccases. ${ }^{[50]}$

After pretreatment and conditioning, the whole biomass slurry or the washed solids are exposed to cellulolytic enzymes that are produced either on site in a separate reactor or are purchased from an external vendor. The optimal composition of the enzyme mix depends on the pretreatment method, e.g. if the hemicellulose is not solubilized then the enzyme mixture has to be supplemented with hemicellulases. The on-site production of hydrolytic enzymes lowers enzyme costs as formulation and transport is not required, however enzyme companies such as Novozymes argue that the complexity of enzyme production is too high for plant operators, especially because so far not all activities required in advanced enzyme mixtures can be expressed in one host. ${ }^{[27]}$ The action of the hydrolytic enzymes is slow with typical reaction times for almost complete hydrolysis in the range of three to five days under optimized conditions ( $\left.\mathrm{T}=45-50{ }^{\circ} \mathrm{C}, \mathrm{pH} 4.8\right)$. The enzymes are typically inhibited by their reaction products, i.e. the sugars. ${ }^{[51]}$ Thus, it can be advantageous to combine enzymatic hydrolysis and fermentation of the sugars in one step, a process configuration termed 'simultaneous saccharification and fermentation' (SSF). ${ }^{[52]}$

The third main unit operation of the production process is the fermentation of the released C5 and C6 sugars to ethanol either separately or together by appropriate microorganisms. While ethanologenic fermentation of glucose, mannose and galactose by e.g. S. cerevisiae or Z. mobilis is well established on industrial scale, the conversion of the pentose sugars xylose and arabinose to ethanol in high yields is more challenging especially in the presence of hexoses. ${ }^{[53]}$ Therefore, a lot of research effort has been put into obtaining improved recombinant strains of bacteria or yeast capable of pentose conversion, leading nowadays to commercially available co-fermenting yeast strains. ${ }^{[11]}$

Ethanol is finally recovered from the fermentation broth by enrichment in the beer tower followed by rectification to $96 \% \mathrm{v} / \mathrm{v}$ ethanol and final dehydration to $100 \%$ ethanol. For an economically viable distillation process, the ethanol concentration in the broth should be at least $4 \%$ $\mathrm{v} / \mathrm{v} \cdot{ }^{[54]}$ In starch or sucrose fermentation, ethanol concentration of up to $15 \% \mathrm{v} / \mathrm{v}$ are reached, but this cannot be achieved in lignocellulose conversion, as insoluble biomass can simply not be mixed at high concentrations. For instance, an aqueous mixture of about $10 \% \mathrm{w} / \mathrm{w}$ loose straw contains no free water and as biomass contains only about two-thirds carbohydrates the fermentation yields at maximum about $5 \% \mathrm{v} / \mathrm{v}$ ethanol. ${ }^{[1]}$ Finally, the remaining lignin and other solid biomass residues are burned to provide heat and power for the plant, with excess electrical power being exported to the grid.

Despite the higher complexity of biological cellulosic ethanol production compared to first-generation ethanol production, the first commercial plants have been put into operation or are scheduled to open soon (Table 1).

Information about operating conditions and performance of these plants are proprietary, but an overview about a hypothetical commercial plant can be obtained from the design reports by the National Renewal Energy Laboratory (NREL) issued in 1999, 2002, and 2011. The 2011 design report describes an ethanol plant with an annual ethanol output of about 230 million liter using 730'000 dry tons of corn stover. ${ }^{[56]}$ This translates to a biomass collection radius of 50 miles in the corn belt of the US, if $10 \%$ of the stover in this area is available to the plant. The biomass is pretreated in a two-stage process: First, biomass is treated at $158{ }^{\circ} \mathrm{C}$ with saturated steam in a continuous horizontal reactor with a residence time of $5 \mathrm{~min}$ and an sulfuric acid loading of $18 \mathrm{mg}$ per $\mathrm{g}$ of corn stover. In the second 
Table 1. Examples of commercial-scale cellulosic ethanol projects using the sugar platform currently in operation or expected to open. ${ }^{[55]}$

\begin{tabular}{|l|l|l|l|l|}
\hline Company & Location & Feedstock & Pretreatment & $\begin{array}{l}\text { Capacity } \\
10^{6} \text { L/year }\end{array}$ \\
\hline $\begin{array}{l}\text { Beta Re- } \\
\text { newables }\end{array}$ & $\begin{array}{l}\text { Crescentino, } \\
\text { Italy }\end{array}$ & Wheat straw & Steam explosion & 76 \\
\hline $\begin{array}{l}\text { Abengoa } \\
\text { Bioenergy }\end{array}$ & $\begin{array}{l}\text { Hugoton, Kan- } \\
\text { sas, USA }\end{array}$ & $\begin{array}{l}\text { Corn stover, wheat } \\
\text { straw, grasses }\end{array}$ & $\begin{array}{l}\text { Acid impreg- } \\
\text { nation, steam } \\
\text { explosion }\end{array}$ & 95 \\
\hline Poet DSM & $\begin{array}{l}\text { Emmetsburg, } \\
\text { Iowa, USA }\end{array}$ & Corn stover and cobs & $\begin{array}{l}\text { Two stage steam } \\
\text { explosion } \\
\text { Steam explosion }\end{array}$ & 76 \\
\hline GranBio & Alaogas, Brazil & Sugarcane straw & Stania & 95 \\
\hline $\begin{array}{l}\text { DuPont } \\
\text { Danisco }\end{array}$ & $\begin{array}{l}\text { Nevada, Iowa, } \\
\text { USA }\end{array}$ & Corn stover & Dilute ammonia & 95 \\
\hline
\end{tabular}

step, an additional $4.1 \mathrm{mg} / \mathrm{g}$ of sulfuric acid is added and the mixture is held at $130{ }^{\circ} \mathrm{C}$ for 20-30 minutes to hydrolyze xylose oligomers under relatively mild conditions. After the pretreatment, water and ammonia are added yielding a suspension with $\mathrm{pH} 5$ and a total solid (soluble and insoluble) loading of about $20 \% \mathrm{w} / \mathrm{w}$. Cellulase necessary for the enzymatic hydrolysis is considered to be produced on-site in a 5-day aerobic fermentation in a $300 \mathrm{~m}^{3}$ aerated reactor employing glucose as substrate. Enzymatic hydrolysis is performed as a separate process from fermentation and is initiated in a $950 \mathrm{~m}^{3}$ continuous reactor at $47^{\circ} \mathrm{C}$ with a residence time of $24 \mathrm{~h}$ and an enzyme loading of $20 \mathrm{mg}$ per $\mathrm{g}$ of cellulose. After that, the now pumpable mixture is batched in one of the twelve $3600 \mathrm{~m}^{3}$ vessels where the hydrolysis continues for further $60 \mathrm{~h}$. Next, the hydrolyzed slurry containing $6.7 \%$ w/w monomeric glucose and $3.7 \% \mathrm{w} / \mathrm{w}$ monomeric xylose is cooled to $32{ }^{\circ} \mathrm{C}$ and inoculated with the co-fermenting microorganism Zymomonas mobilis $(10 \% \mathrm{v} / \mathrm{v})$. After 1.5 days, the fermentation is finished at a concentration of $5.4 \% \mathrm{w} / \mathrm{w}$.

The techno-economic study enabled a detailed cost projection of cellulosic ethanol production in the above-described plant. Based on a corn stover price of 58 US \$/ton and a total capital investment of around 425 million dollars, the minimal selling price was calculated to $0.57 \$$ per liter ethanol ( $2.15 \$ / g a l)$ corresponding to about 0.90 \$ per liter gasoline equivalent. The main cost drivers are capital costs (the sum of capital depreciation and average return on investment, $36 \%$ ), feedstock $(34 \%)$, and enyzmes $(16 \%)$. The largest contributors to the capital costs are the boiler/turbogenerator $(28 \%)$, wastewater treatment facilities (21\%), enzymatic hydrolysis and fermentation equipment $(13 \%)$ and pretreatment equipment $(13 \%)$. Overall, these cost estimates are quite optimistic and others state higher numbers, e.g. Wyman and Dale estimated costs of $\$$ $1.00 /$ gal ethanol (\$ 0.27/L) each for feedstock, enzymes and capital costs. ${ }^{[11]}$ Thus reducing enzyme and capital costs while conserving high yields remain important goals for competitive cellulosic ethanol production.

\subsection{Consolidated Bioprocessing by Engineered Microorganisms}

One approach to reduce enzyme and capital costs is the simplification of the process by a strategy typically referred to as consolidated bioprocessing (CBP) which combines the production of cellulolytic enzymes, the enzymatic hydrolysis of the sugar polymers and the fermentation of the sugars to ethanol in one reactor. Once realized, cost savings of up to $40 \%$ compared to the state of the art SSF process have been estimated. ${ }^{[57]}$

Table 2. Overview of characteristics of some possible CBP strains. ${ }^{[25,29,58,60]}$

\begin{tabular}{|c|c|c|c|c|}
\hline & \multicolumn{2}{|l|}{ Native strategy } & \multicolumn{2}{|c|}{ Recombinant strategy } \\
\hline & $\begin{array}{l}\text { Clostridia } \\
\text { thermocellum } \\
\text { (bacteria) }\end{array}$ & $\begin{array}{l}\text { Fusarium oxy- } \\
\text { sprorum (fungi) }\end{array}$ & $\begin{array}{l}S . \text { cerevesiae } \\
\text { (yeast) }\end{array}$ & $\begin{array}{l}\text { E coli } \\
\text { (bacteria) }\end{array}$ \\
\hline $\begin{array}{l}\text { Cellulase } \\
\text { production }\end{array}$ & Yes, cellulosome & $\begin{array}{l}\text { Yes, free en- } \\
\text { zyme }\end{array}$ & no & no \\
\hline $\begin{array}{l}\text { Ethanol pro- } \\
\text { duction }\end{array}$ & $\begin{array}{l}\text { low, with by- } \\
\text { products }\end{array}$ & moderate & excellent & good \\
\hline $\begin{array}{l}\text { Ethanol tol- } \\
\text { erance }\end{array}$ & low & medium & high & high \\
\hline $\begin{array}{l}\text { Pentose fer- } \\
\text { mentation }\end{array}$ & no & yes & no & yes \\
\hline $\begin{array}{l}\text { Availability } \\
\text { of genetic } \\
\text { tools }\end{array}$ & limited & limited & high & high \\
\hline Comments & \multicolumn{2}{|c|}{$\begin{array}{l}\text { - Inherent regulation allows organ- } \\
\text { isms to adjust enzyme levels as } \\
\text { required for different substrates } \\
\text { - High yield, titer and robustness } \\
\text { under industrial conditions are } \\
\text { challenging }\end{array}$} & \multicolumn{2}{|c|}{$\begin{array}{l}\text { - Co-expression of several } \\
\text { heterologous cellulase genes } \\
\text { is a substantial burden on the } \\
\text { secretion pathway }\end{array}$} \\
\hline
\end{tabular}

\subsubsection{Native Strategy}

The range of desirable traits for an industrially viable CBP strain is highly demanding and includes i) the production of sufficient levels of cellulase, ii) balanced growth on pentoses and hexoses, iii) tolerance to ethanol, pretreatment inhibitors and process fluctuations and iv) maximal product yield and productivities. ${ }^{[28,58]}$ Two main strategies are employed for the engineering of CBP strains. The native strategy uses cellulolytic organisms as a starting point to introduce the desired product formation capabilities by metabolic engineering, whereas in the recombinant strategy superior ethanol-producing organisms are engineered for heterologous cellulase expression to enable hemicellulose and cellulose utilization. ${ }^{59]}$ So far, it is not clear which strategy will ultimately be more successful as both have strength and weaknesses (Table 2).

Several CBP candidates are considered for the native strategy and belong to the groups of cellulosome-forming bacteria, fungi and free-enzyme bacteria. ${ }^{[59]}$ Among the cellulosome-forming bacteria, the one probably receiving most attention is Clostridium thermocellum, an anaerobic thermophile first isolated in 1926. ${ }^{[61]}$ This strain can hydrolyze cellulose and hemicellulose at fast rates and can metabolize C6 sugars to ethanol. The drawbacks are low ethanol tolerance, the diverse product spectrum and the inability to consume pentose sugars. However, knockout of two genes responsible for organic acid production and $2000 \mathrm{~h}$ evolution resulted in a C. thermocellum variant with a 40:1 etha- 
nol selectivity and 4.2 fold higher ethanol yield compared to the wild type. ${ }^{[62]}$

Fungal species that are discussed as promising CBP candidates include $T$. reesei, Aspergillus spp or Fusarium spp, but for the strains that are not naturally ethanologenic, research is still in its infancy. ${ }^{[63]}$ One example for a native cellulolytic and ethanologenic microorganism is Fusarium oxysporum, that was reported to produce $9.6 \mathrm{~g} / \mathrm{L}$ ethanol in 6 days from $20 \mathrm{~g} / \mathrm{L}$ cellulose. ${ }^{[64]}$

Recently, Caldicellulosiruptor bescii, an anaerobic bacterium expressing free cellulase, was studied in more detail and engineered for ethanol production. This strain has an optimal growth temperature of $80^{\circ} \mathrm{C}$ and is able to assimilate cellulose, hemicellulose and lignin from unpretreated switchgrass. ${ }^{[65]}$ After deletion of lactate de- hydrogenase and heterologous expression of a $C$. thermocellum acetaldehyde/alcohol dehydrogenase, $70 \%$ of the fermentation product spectrum (ethanol, acetate, lactate; $\mathrm{H}_{2}$ ) was ethanol. From $20 \mathrm{~g} / \mathrm{L}$ unpretreated switchgrass, $0.6 \mathrm{~g} / \mathrm{L}$ ethanol could be produced in $60 \mathrm{~h} .{ }^{[66]}$

\subsubsection{Recombinant Strategy}

For CBP, probably the most intensive research efforts started already 25 years ago have been put into the introduction of cellulolytic abilities in $S$. cerevisiae as summarized in several comprehensive reviews. ${ }^{[67]}$ So far, complete conversion of cellulosic substrates has not been achieved by a heterologous $S$. cerevisiae strain and most results are reported only for highly reactive, non-crystalline model substrates such as soluble carboxymethyl cellulose or phosphoric acid swollen cellulose (PASC). However, several important intermediate milestones have been achieved. For example, a $\beta$-glucosidase expressing recombinant yeast was able to grow on cellobiose at comparable rates to those on glucose, thereby allowing the use of $\beta$-glucosidase deficient exogenous enzyme cocktails. ${ }^{[68]}$ Also, partial conversion of pure microcrystalline cellulose (Avicel) was achieved with an engineered $S$. cerevisiae strain secreting $\mathrm{CBH} 1$ and $\mathrm{CBH} 2$ into the medium when grown under aerobic conditions on rich complex medium. In a subsequent anaerobic fermentation, this strain produced $3 \mathrm{~g} / \mathrm{L}$ ethanol from $20 \mathrm{~g} / \mathrm{L}$ Avicel in 7 days, but required addition of $\beta$-glucosidase to prevent cellobiose accumulation. ${ }^{[69]}$ Fan et al. constructed a yeast strain capable of cell surface display of a mini cellulosome

Table 3. Consolidated bioprocesses based on microbial communities for the production of ethanol.

\begin{tabular}{|c|c|c|c|c|}
\hline Microorganisms & Co-culture principle & Substrate $[\mathrm{g} / \mathrm{L}]$ & Ethanol $[\mathrm{g} / \mathrm{L}]$ & Ref. \\
\hline \multicolumn{5}{|l|}{ Natural microbial communities } \\
\hline $\begin{array}{l}\text { Thermoanaerobacterium, } \\
\text { Geobacillusw }\end{array}$ & $\begin{array}{l}\text { Anaerobic Thermoanaerobacterium de- } \\
\text { grades hemicellulose and produces etha- } \\
\text { nol. Geobacillus is an aerobic cellulose } \\
\text { degrader. Under semiaerobic conditions, } \\
\text { Geobacillus produces cellulase and shields } \\
\text { Thermoanaerobacterium from oxygen that } \\
\text { is consumed by the aerobic strain. }\end{array}$ & Bean curd refuse, 10 & 1.3 & [78] \\
\hline $\begin{array}{l}\text { Natural thermophilic consortium } \\
\text { from soil sample enriched with }\end{array}$ & $\begin{array}{l}\text { P. taiwanensis increases ethanol yield by } \\
20 \%\end{array}$ & $\alpha$-cellulose, 7 & 2.5 & [79] \\
\hline
\end{tabular}

P. taiwanensis

Synthetic microbial communities of wild-type microorganisms

Caldicellulosiruptur DIB 004C,

Thermoanaerobacter DIB 004G

\section{Clostridium thermocellum,}

Clostridium thermolacticum

C. thermocellum,

Thermoanaerobacter

T. reesei RutC30, S. cerevisiae, S. stipitis

\section{Unknown symbiosis, co-culture produced 2.4 times more ethanol than monoculture of Caldicellulosiruptur DIB 004C}

Unknown symbiosis, 2.8 times more ethanol than in monoculture of $C$. thermocellum

Cellulolytic strain $C$. thermocellum combinded with ethanologenic strain, 4.6 times higher yield in co-culture on $10 \mathrm{~g} / \mathrm{L}$ Solka Floc

T. reesei for cellulase production, $S$. cerevisiae for ethanol fermentation from hexoses, S. stipits for ethanol production from pentoses. Locally defined aeration through a membrane enables the necessary concomitant aerobic and anaerobic conditions in one reactor.

Avicel, 20

3.3

Micro-crystalline

cellulose, 10

Solka Floc, 50

dilute acid pretreated

10

wheat straw, 17.5

cellulose

Birchwood xylan, $20 \quad 2.8$

One E. coli strain expresses two xylanase gene, the other one ferments xylooligosaccharides to ethanol

2 E. coli strains

4 S. cerevisae strains

C. thermocellum, T. saccharolyticum
Construction of surface displayed minicellulosome. Division of labor between 4 yeast strains expressing $\mathrm{CBH}, \mathrm{EG}, \mathrm{BG}$ and a trifunctional scaffoldin
PASC, 10

Unknown synergy

Avicel, 92 
with cellulases from $C$. cellulolyticum, that for the first time was able to convert crystalline cellulose $(10 \mathrm{~g} / \mathrm{L}$ Avicel $)$ to ethanol ( $1.4 \mathrm{~g} / \mathrm{L}$ after 4 days), however at very high cell density $(\mathrm{OD} 600=50)$. ${ }^{[70]}$

An example of a bacterial host for cellulase expression and ethanol fermentation is $E$. coli, that was engineered to produce $3.6 \mathrm{~g} / \mathrm{L}$ ethanol from $10 \mathrm{~g} / \mathrm{L}$ PASC and $0.3 \mathrm{~g} / \mathrm{L}$ ethanol from $1 \mathrm{~g} / \mathrm{L}$ pretreated corn stover cellulose. ${ }^{[71]}$

Despite ongoing research efforts, no industrially viable CBP strain has been created so far and efficient hydrolysis of real lignocellulosic substrates in high gravity, low cost fermentation media remains a significant hurdle. ${ }^{[58]}$

\subsection{Consolidated Bioprocessing by Co-cultures and Microbial com- munities}

The application of microbial consortia for consolidated bioprocessing of lignocellulosic biomass to ethanol and other fermentation products is a promising alternative to the utilization of one genetically engineered 'superbug' that has received growing interest in recent years. ${ }^{[72-74]}$ In nature, most microorganisms form diverse communities enabling them to perform complex tasks that are not possible by a single species. ${ }^{[75]}$ The high complexity of such natural communities characterized by a huge number of different microorganisms often of unknown identity, that interact by several possible mechanisms such as symbiosis, cooperation and competition, makes targeted engineering of a desired trait difficult. However, the production of ethanol by natural communities has also been attempted, but yields remain modest (Table 3) despite excellent degradation of the lignocellulosic substrates.

The construction of synthetic microbial communities, with the simplest ones being co-cultures of two species, allows the generation of defined systems with reduced complexity that can be employed for the biotechnological production of a target chemical. ${ }^{[72]}$ This approach enables the division of labour between several microbes either by combining natural specialists or by the compartmentalization of the required multiple heterologous metabolic pathways into different hosts thereby avoiding genetic instability and metabolic overload. ${ }^{[73]}$ Finding matching fermentation conditions (e.g. $\mathrm{pH}$, temperature, aeration) in co-cultures can be challenging and typically systems are used that are either aerobic or anaerobic. To overcome this limitation and to be able to combine the two dominant microorganisms of industrial cellulosic ethanol production, i.e. T. reesei and $S$. cerevisiae, we developed in our laboratory a membrane-aerated biofilm reactor. This reactor was aerated through a dense, oxygen-permeable membrane that served the aerobic, cellulase-producing fungus $T$. reese $i$ as a growth basis. The T. reesei biofilm consumes all oxygen entering the system and allows for anaerobic conditions in the upper part of the biofilm and in the liquid slurry, which is necessary for ethanol production by $S$. cerevisiae. ${ }^{[76]}$

An overview about the performance of this and other multispecies systems that have been employed for the production of ethanol can be found in Table 3. Especially the co-cultures combining cellulolytic and fermenting strains display attractive modular systems that offer the possibility to readily adapt them for production of many other biochemicals. For example, the above-described membrane reactor was also employed for the production of lactic acid (see Table 4). ${ }^{[77]}$

\section{Production of Chemicals and Advanced Fuels}

Lignocellulosic biomass is also an interesting alternative feedstock for the chemical industry producing commodity chemicals or advanced biofuels. To stimulate research efforts towards the development of a bio-based chemical industry, the DOE issued in 2004 a list of 12 platform

Table 4. Production of commodity chemicals other than ethanol from lignocelluosic biomass by different CBP strategies.

\begin{tabular}{|c|c|c|c|}
\hline Microorganisms & Substrate, conc. $[\mathrm{g} / \mathrm{L}]$ & Product, conc. $[\mathrm{g} / \mathrm{L}]$ & Ref. \\
\hline \multicolumn{4}{|l|}{ Natural microbial communities } \\
\hline $\begin{array}{l}\text { Consortium from rumen fluid, } \\
\text { compost and swamp material }\end{array}$ & $\begin{array}{l}80 \% \text { lime pretreated } \\
\text { corn stover, } 20 \% \text { pig } \\
\text { manure, not stated. }\end{array}$ & $\begin{array}{l}\text { Mixed carboxylic } \\
\text { acids, } 24.4\end{array}$ & [89] \\
\hline \multicolumn{4}{|c|}{ Synthetic consortium of wild type microorganisms } \\
\hline $\begin{array}{l}\text { Clostridium cellulovorans; } \\
\text { Clostridium beijerinckii }\end{array}$ & $\begin{array}{l}\text { Alkali extracted des- } \\
\text { helled corn cob, not } \\
\text { stated }\end{array}$ & $\begin{array}{l}\text { Acetone, butanol, } \\
\text { ethanol, } 11.8\end{array}$ & [90] \\
\hline C. acremonium, $R$. oryzae & Corn cobs, 100 & Lactic acid, 24 & [91] \\
\hline $\begin{array}{l}\text { T. reesei, Lactobacillus } \\
\text { delbrueckii }\end{array}$ & Avicel, 17.5 & Lactic acid, 8.4 & [77] \\
\hline
\end{tabular}

Synthetic consortium of genetically engineered microorganisms

Cellulolytic E. coli, xylanolytic Ionic liquid pretreated Butanol, 0.028

E. coli switchgrass, 33

Cellulolytic E. coli, xylanolytic Ionic liquid pretreated Fatty acid ethyl

$\begin{array}{lll}\text { E. coli } & \text { switchgrass, } 33 & \text { esters, } 0.071\end{array}$

Cellulolytic E. coli, xylanolytic Ionic liquid pretreated Pinene, 0.0017

E. coli switchgrass, 33

T. reesei, E. coli

AFEX pretreated corn Isobutanol, 1.88 stover, 20

CBP microorganisms

Bacillus subtilis

PASC, 6.3

Lactate, 4.1,

Clostridium cellulolyticum

Avicel, 10

Isobutanol, 0.66

Streptomyces lividans

PASC, 10

4-vinylphenol, 0.25 


\section{Conclusions}

The promise of lignocellulosic biomass as renewable feedstock with the potential to substitute a significant fraction of today's fossil fuel consumption is being currently realized with the first commercial scale cellulosic ethanol plants already operating. However, the operations required to overcome the natural recalcitrance of lignocellulosic biomass to release fermentable sugars, i.e. the pretreatment and enzymatic hydrolysis, are still challenging especially with respect to process economics. Promising strategies for cost reduction are the development of more efficient pretreatment technologies and cellulase cocktails as well as the development of consolidated bioprocesses, either by genetic engineering or by employing artificial microbial consortia. Success in these endeavors opens up the path towards a real bioeconomy, where also commodity chemicals are produced in biorefineries converting lignocellulosic biomass.

Received: June 29, 2015

[1] A. J. Ragauskas, C. K. Williams, B. H. Davison, G. Britovsek, J. Cairney, C. A. Eckert, W. J. Frederick, J. P. Hallett, D. J. Leak, C. L. Liotta, J. R. Mielenz, R. Murphy, R. Templer, T. Tschaplinski, Science 2006, 311, 484.

[2] B. Kamm, M. Kamm, Appl. Microbiol. Biotechnol. 2004, 64, 137.

[3] F. Cherubini, G. Jungmeier, M. Wellisch, T. Willke, I. Skiadas, R. van Ree, E. de Jong, Biofuels, Bioprod. Bioref. 2009, 3, 534.

[4] K. A. Gray, L. Zhao, M. Emptage, Curr. Opin. Chem. Biol. 2006, 10, 141.

[5] L. J. Gibson, J. Roy. Soc. Interface 2012, 9, 2749.

[6] Y.-H. P. Zhang, L. R. Lynd, Biotechnol. Bioeng. 2004, 88, 797.

[7] F. M. Gírio, C. Fonseca, F. Carvalheiro, L. C. Duarte, S. Marques, R. Bogel-Łukasik, Bioresour. Technol. 2010, 101, 4775.

[8] X. Zhao, L. Zhang, D. Liu, Biofuels, Bioprod. Bioref. 2012, 6, 465 .

[9] Y. Pu, D. Zhang, P. M. Singh, A. J. Ragauskas, Biofuels, Bioprod. Bioref. 2008, 2, 58.

[10] M. E. Himmel, S.-Y. Ding, D. K. Johnson, W. S. Adney, M. R. Nimlos, J. W. Brady, T. D. Foust, Science 2007, 315, 804.

[11] L. R. Lynd, C. E. Wyman, T. U. Gerngross, Biotechnol. Prog. 1999, 15, 777.

[12] a) V. B. Agbor, N. Cicek, R. Sparling, A. Berlin, D. B. Levin, Biotechnol. Adv. 2011, 29, 675; b) A. T. W. M. Hendriks, G. Zeeman, Bioresour. Technol. 2009, 100, 10; c) N. Mosier, Bioresour. Technol. 2005, 96, 673; d) C. E. Wyman, B. E. Dale, R. T. Elander, M. Holtzapple, Ladisch, Y. Y. Lee, Bioresour. Technol. 2005, 96, 1959.

[13] a) H. H. Brownell, J. N. Saddler, Biotechnol. Bioeng. 1987, 29, 228; b) K. Ohgren, R. Bura, J. Saddler, G. Zacchi, Bioresour. Technol. 2007, 98, 2503.

[14] N. Mosier, R. Hendrickson, N. Ho, M. Sedlak, M. R. Ladisch, Bioresour. Technol. 2005, 96, 1986.

[15] K. Stenberg, C. Tengborg, M. Galbe, G. Zacchi, J. Chem. Technol. Biotechnol. 1998, 71, 299.

[16] T. A. Lloyd, C. E. Wyman, Bioresour. Technol. 2005, 96, 1967.
[17] C. C. Geddes, J. J. Peterson, C. Roslander, G. Zacchi, M. T. Mullinnix, K. T. Shanmugam, L. O. Ingram, Bioresour. Technol. 2010, 101, 1851.

[18] M. W. Lau, B. E. Dale, Proc. Natl. Acad. Sci. U.S.A. 2009, 106, 1368.

[19] C. Li, B. Knierim, C. Manisseri, R. Arora, H. V. Scheller, M. Auer, K. P. Vogel, B. A. Simmons, S. Singh, Bioresour. Technol. 2010, 101, 4900.

[20] T. Y. Nguyen, C. M. Cai, R. Kumar, C. E. Wyman, ChemSusChem 2015, 8, 1716.

[21] da Costa Sousa, Leonardo, Chundawat, Shishir P S, V. Balan, B. E. Dale, Curr. Opin. Biotechnol. 2009, 20, 339.

[22] J. L. Linville, M. Rodriguez, M. Land, M. H. Syed, N. L. Engle, T. J. Tschaplinski, J. R. Mielenz, C. D. Cox, S. S. Fong, PLoS ONE 2013, 8, e78829.

[23] L. Tao, A. Aden, R. T. Elander, V. R. Pallapolu, Y. Y. Lee, R. J. Garlock, V. Balan, B. E. Dale, Y. Kim, N. S. Mosier, M. R. Ladisch, M. Falls, M. T. Holtzapple, R. Sierra, J. Shi, M. A. Ebrik, T. Redmond, B. Yang, C. E. Wyman, B. Hames, S. Thomas, R. E. Warner, Bioresour. Technol. 2011, 102, 11105 .

[24] a) M. T. Holtzapple, A. E. Humphrey, J. D. Taylor, Biotechnol. Bioeng. 1989, 33, 207; b) B. C. Vidal, B. S. Dien, K. C. Ting, V. Singh, Appl. Biochem. Biotechnol. 2011, 164, 1405.

[25] C. Lambertz, M. Garvey, J. Klinger, D. Heesel, H. Klose, R. Fischer, U. Commandeur, Biotechnol. Biofuels 2014, 7, 135.

[26] J. Sheehan, M. Himmel, Biotechnol. Prog. 1999, 15,817 .

[27] M. Zoglowek, P. S. Lübeck, B. K. Ahring, M. Lübeck, Process Biochem. 2015, 50, 211.

[28] J. G. Elkins, B. Raman, M. Keller, Curr. Opin. Biotechnol. 2010, 21, 657.

[29] M. Garvey, H. Klose, R. Fischer, C. Lambertz, U. Commandeur, Trends Biotechnol. 2013, 31, 581.

[30] P. Bansal, M. Hall, M. J. Realff, J. H. Lee, A. S. Bommarius, Biotechnol. Adv. 2009, 27, 833.

[31] U. Bornscheuer, K. Buchholz, J. Seibel, Angew. Chem. Int. Ed. 2014, 53, 10876.

[32] A. S. Bommarius, A. Katona, S. E. Cheben, A. S. Patel, A. J. Ragauskas, K. Knudson, Y. Pu, Metab. Eng. 2008, 10, 370 .

[33] L. R. Lynd, P. J. Weimer, W. H. van Zyl, I. S. Pretorius, Microbiol. Mol. Biol. Rev. 2002, 66, 506.

[34] A. A. Klyosov, in 'Biochemistry and genetics of cellulose degradation', Ed. J.-P. Aubert, P. Beguin, J. Millet, Academic Press, London, 1988, p. 97.

[35] D. B. Wilson, Curr. Opin. Biotechnol. 2009, 20, 295.

[36] L. R. Lynd, Zyl, Willem H van, J. E. McBride, M. Laser, Curr. Opin. Biotechnol. 2005, 16, 577 .

[37] E. A. Bayer, H. Chanzy, R. Lamed, Y. Shoham, Curr. Opin. Struct. Biol. 1998, 8, 548.

[38] A. Rentmeister, Chem. Ing. Tech. 2013, 85, 818.

[39] S. Moraïs, E. Morag, Y. Barak, D. Goldman, Y. Hadar, R. Lamed, Y. Shoham, D. B. Wilson, E. A. Bayer, mBio 2012, 3.

[40] S. P. Voutilainen, H. Boer, M. Alapuranen, J. Jänis, J. Vehmaanperä, A. Koivula, Appl. Microbiol. Biotechnol. 2009, 83, 261.

[41] S. P. Voutilainen, P. G. Murray, M. G. Tuohy, A. Koivula, Protein Eng. Des. Sel. 2010, 23, 69.

[42] P. Heinzelman, C. D. Snow, I. Wu, C. Nguyen, A. Villalobos, S. Govindarajan, J. Minshull, F. H. Arnold, Proc. Natl. Acad. Sci. U.S.A. 2009 , 106,5610 .

[43] A. S. Bommarius, M. Sohn, Y. Kang, J. H. Lee, M. J. Realff, Curr. Opin. Biotechnol. 2014, 29, 139.

[44] R. J. Quinlan, M. D. Sweeney, L. Lo Leggio, H. Otten, J.-C. N. Poulsen, K. S. Johansen, Krogh, Kristian B R M, C. I. Jørgensen, M. Tovborg, A. Anthonsen, T. Tryfona, C. P. Walter, P. Dupree, F. Xu, G. J. Davies, P. H. Walton, Proc. Natl. Acad. Sci. U.S.A. 2011, 108, 15079.
[45] G. Vaaje-Kolstad, B. Westereng, S. J. Horn, Z. Liu, H. Zhai, M. Sørlie, V. G. H. Eijsink, Science 2010, 330, 219.

[46] G. Jäger, M. Girfoglio, F. Dollo, R. Rinaldi, H. Bongard, U. Commandeur, R. Fischer, A. C. Spiess, J. Büchs, Biotechnol. Biofuels 2011, 4, 33.

[47] Sekab, http://www.sekab.com/biofuel/ed $95 /$.

[48] C. C. Geddes, I. U. Nieves, L. O. Ingram, Curr. Opin. Biotechnol. 2011, 22, 312.

[49] S. Brethauer, C. E. Wyman, Bioresour. Technol. 2010, 101, 4862.

[50] H. B. Klinke, A. B. Thomsen, B. K. Ahring, Appl. Microbiol. Biotechnol. 2004, 66, 10.

[51] G. P. Philippidis, T. K. Smith, C. E. Wyman, Biotechnol. Bioeng. 1993, 41, 846.

[52] K. Olofsson, M. Bertilsson, G. Lidén, Biotechnol. Biofuels 2008, 1, 7.

[53] B. Hahn-Hägerdal, K. Karhumaa, C. Fonseca, I. Spencer-Martins, M. F. Gorwa-Grauslund, Appl. Microbiol. Biotechnol. 2007, 74, 937.

[54] L. M. Vane, Biofuels, Bioprod. Bioref. 2008, 2, 553.

[55] T. R. Brown, R. C. Brown, V. Estes, Chem. Eng. Prog. 2015, 111, 62.

[56] D. Humbird, R. Davis, L. Tao, C. Kinchin, D. Hsu, A. Aden, P. Schoen, J. Lukas, B. Olthof, M. Worley, D. Sexton, D. Dudgeon, Technical Report NREL/TP-5100-47764, 2011.

[57] L. R. Lynd, M. S. Laser, D. Bransby, B. E. Dale, B. Davison, R. Hamilton, M. Himmel, M. Keller, J. D. McMillan, J. Sheehan, C. E. Wyman, Nat. Biotechnol. 2008, 26, 169.

[58] R. den Haan, E. van Rensburg, S. H. Rose, J. F. Görgens, van Zyl, Willem H, Curr. Opin. Biotechnol. 2015, 33, 32.

[59] D. G. Olson, J. E. McBride, A. J. Shaw, L. R. Lynd, Curr. Opin. Biotechnol. 2012, 23, 396.

[60] Q. Xu, A. Singh, M. E. Himmel, Curr. Opin. Biotechnol. 2009, 20, 364.

[61] H. Akinosho, K. Yee, D. Close, A. Ragauskas, Front. Chem. 2014, 2.

[62] D. A. Argyros, S. A. Tripathi, T. F. Barrett, S. R. Rogers, L. F. Feinberg, D. G. Olson, J. M. Foden, B. B. Miller, L. R. Lynd, D. A. Hogsett, N. C. Caiazza, Appl. Environ. Microb. 2011, 77, 8288.

[63] A. Amore, V. Faraco, Renew. Sust. Energ. Rev. 2012, 16, 3286.

[64] P. Christakopoulos, B. J. Macris, D. Kekos, Enzyme Microb. Technol. 1989, 11, 236.

[65] I. Kataeva, M. B. Foston, S.-J. Yang, S. Pattathil, A. K. Biswal, Poole II, Farris L., M. Basen, A. M. Rhaesa, T. P. Thomas, P. Azadi, V. Olman, T. D. Saffold, K. E. Mohler, D. L. Lewis, C. Doeppke, Y. Zeng, T. J. Tschaplinski, W. S. York, M. Davis, D. Mohnen, Y. Xu, A. J. Ragauskas, S.-Y. Ding, R. M. Kelly, M. G. Hahn, M. W. W. Adams, Energy Environ. Sci. 2013, 6, 2186.

[66] D. Chung, M. Cha, A. M. Guss, J. Westpheling, Proc. Natl. Acad. Sci. U.S.A. 2014, 111, 8931.

[67] a) R. den Haan, H. Kroukamp, M. Mert, M. Bloom, J. F. Görgens, W. H. van Zyl, J. Chem. Technol. Biotechnol. 2013, 88, 983; b) T. Hasunuma, A. Kondo, Biotechnol. Adv. 2012, 30, 1207; c) T. Hasunuma, F. Okazaki, N. Okai, K. Y. Hara, J. Ishii, A. Kondo, Bioresour. Technol. 2013, 135, 513.

[68] C. Wilde, N. D. Gold, N. Bawa, J. H. Tambor, L. Mougharbel, R. Storms, V. J. Martin, Appl. Microbiol. Biotechnol. 2012, 95, 647.

[69] M. Ilmén, R. den Haan, E. Brevnova, J. McBride, E. Wiswall, A. Froehlich, A. Koivula, S. P. Voutilainen, M. Siika-Aho, D. C. la Grange, N. Thorngren, S. Ahlgren, M. Mellon, K. Deleault, V. Rajgarhia, W. H. van Zyl, M. Penttilä, Biotechnol. Biofuels 2011, 4, 30.

[70] L.-H. Fan, Z.-J. Zhang, X.-Y. Yu, Y.-X. Xue, T.W. Tan, Proc. Natl. Acad. Sci. U.S.A. 2012, 109, 13260.

[71] S. Ryu, M. N. Karim, Appl. Microbiol. Biotechnol. 2011, 91, 529. 
[72] N. Jagmann, B. Philipp, J. Biotechnol. 2014, 184, 209.

[73] J. Shong, Jimenez Diaz, Manuel Rafael, C. H. Collins, Curr. Opin. Biotechnol. 2012, 23, 798.

[74] T. R. Zuroff, W. R. Curtis, Appl. Microbiol. Biotechnol. 2012, 93, 1423.

[75] H.-C. Chiu, R. Levy, E. Borenstein, C. A Ouzounis, PLoS Comput. Biol. 2014, 10 e1003695.

[76] S. Brethauer, M. H. Studer, Energy Environ. Sci. 2014, 7, 1446

[77] R. Shahab, Diplomarbeit ETH Zürich, TU Berlin, 2014

[78] K. Miyazaki, C. Irbis, J. Takada, A. Matsuura, Bioresour. Technol. 2008, 99, 1768.

[79] R. Du, J. Yan, S. Li, L. Zhang, S. Zhang, J. Li G. Zhao, P. Qi, Biotechnol. Biofuels 2015, 8, 506.

[80] V. A. Svetlitchnyi, O. Kensch, D. A. Falkenhan, S. G. Korseska, N. Lippert, M. Prinz, J. Sassi, A. Schickor, S. Curvers, Biotechnol. Biofuels 2013, 6,31 .

[81] L. Xu, U. Tschirner, Bioresour. Technol. 2011, 102, 10065.
82] Q. He, C. L. Hemme, H. Jiang, Z. He, J. Zhou, Bioresour. Technol. 2011, 102, 9586.

[83] H.-D. Shin, S. McClendon, T. Vo, R. R. Chen, Appl. Environ. Microb. 2010, 76, 8150.

[84] S.-L. Tsai, G. Goyal, W. Chen, Appl. Environ. Microb. 2010, 76, 7514.

[85] T. Werpy, G. Petersen, U.S. Departement of Energy, DOE/GO-102004-1992, 2004.

[86] J. J. Bozell, G. R. Petersen, Green Chem. 2010, $12,539$.

[87] S. Choi, C. W. Song, J. H. Shin, S. Y. Lee, Metab. Eng. 2015, 28, 223.

[88] a) M. G. Adsul, M. S. Singhvi, S. A. Gaikaiwari, D. V. Gokhale, Bioresour. Technol. 2011, 102 , 4304; b) J. Akhtar, A. Idris, R. Abd Aziz, Appl. Microbiol. Biotechnol. 2014, 98, 987; c) S. K. Maity, Renew. Sust. Energ. Rev. 2015, 43, 1427.

[89] P. Thanakoses, A. S. Black, M. T. Holtzapple, Biotechnol. Bioeng. 2003, 83, 191.

[90] Z. Wen, M. Wu, Y. Lin, L. Yang, J. Lin, P. Cen, Microb. Cell Fact. 2014, 13, 92.

91] S. Miura, T. Arimura, N. Itoda, L. Dwiarti, J. B. Feng, C. H. Bin, M. Okabe, J. Biosci. Bioeng. 2004, 97,153
[92] G. Bokinsky, P. P. Peralta-Yahya, A. George, B. M. Holmes, E. J. Steen, J. Dietrich, T. Soon Lee, D. Tullman-Ercek, C. A. Voigt, B. A. Simmons, J. D. Keasling, Proc. Natl. Acad. Sci. U.S.A. 2011, 108, 19949.

[93] J. J. Minty, M. E. Singer, S. A. Scholz, C.-H. Bae, J.-H. Ahn, C. E. Foster, J. C. Liao, X. N. Lin, Proc. Natl. Acad. Sci. U.S.A. 2013, 110 14592

[94] X.-Z. Zhang, N. Sathitsuksanoh, Z. Zhu, Y.-H. P. Zhang, Metab. Eng. 2011, 13, 364.

[95] W. Higashide, Y. Li, Y. Yang, J. C. Liao, Appl. Environ. Microb. 2011, 77, 2727.

[96] S. Noda, Y. Kawai, T. Tanaka, A. Kondo, Bioresour. Technol. 2015, 180, 59. 